\title{
Bacteroides fragilis is a potential marker of effective microbiota transplantation in acute graft-versus-host disease treatment
}

\author{
Oleg V. Goloshchapov ${ }^{1}$, Evgenyi A. Bakin ${ }^{1}$, Maxim A. Kucher ${ }^{1}$, Oksana V. Stanevich ${ }^{1}$, Maria A. Suvorova ${ }^{2}$, \\ Vladimir V. Gostev ${ }^{3}$, Oleg S. Glotov ${ }^{4}$, Yury A. Eismont ${ }^{4}$, Dmitry E. Polev ${ }^{5}$, Anastasia Yu. Lobenskaya ${ }^{5}$, \\ Ruslana V. Klementeva ${ }^{1}$, Maria O. Goloshchapova ${ }^{1}$, Ludmila S. Zubarovskaya ${ }^{1}$, Sergey V. Sidorenko ${ }^{3}$, \\ Alexander N. Suvorov ${ }^{6}$, Ivan S. Moiseev ${ }^{1}$, Alexei B. Chukhlovin ${ }^{1}$ \\ ${ }^{1}$ RM Gorbacheva Research Institute of Pediatric Oncology, Hematology and Transplantation, Pavlov University, St. Petersburg, \\ Russia \\ ${ }^{2}$ Explana Research Laboratory, St. Petersburg, Russia \\ ${ }^{3}$ Pediatric Research and Clinical Center of Infectious Diseases, St. Petersburg, Russia \\ ${ }^{4}$ City Hospital No. 40, St. Petersburg, Russia \\ ${ }^{5}$ Cerbalab Ltd, St. Petersburg, Russia \\ ${ }^{6}$ Institute of Experimental Medicine, St. Petersburg, Russia
}

Dr. Oleg V. Goloshchapov, Head, Anesthesiology Department No.3, Pavlov University, L. Tolstoy St. 6-8, 197022 , St. Petersburg, Russia
Phone: + 7 (921) 9792913

E-mail: golocht@yandex.ru

Citation: Goloshchapov OV, Bakin EA, Kucher MA et al. Bacteroides fragilis is a potential marker of effective microbiota transplantation in acute graft-versus-host disease treatment. Cell Ther Transplant 2020; 9(2): 47-59.

\section{Summary}

Fecal microbiota transplantation (FMT), as any other medical procedure, requires standardization of results, approaches, monitoring of its dynamics and microbiota engraftment evaluation. The aim of the present study was to compare efficiency and results of PCR and 16S RNA-based sequencing in order to trace the dynamics of microbiota composition after FMT.

\section{Patients and methods}

The prospective, single-center study included 27 patients with acute intestinal and chronic (overlap syndrome) graft-versus-host disease (GvHD) developed after allogeneic hematopoietic stem cell transplantation (HSCT). FMT in 19 cases was performed, mostly, with ingestible capsules, eight placebo-treated patients were included into control group. Quantitative changes of different bacterial groups in fecal microbiota were assessed by means of real-time multiplex PCR, being compared with16S rRNA sequencing technique at the terms of $\mathrm{D}+3, \mathrm{D}+16, \mathrm{D}+30, \mathrm{D}+60$ and $\mathrm{D}+120$ following FMT. Clinical response was determined by 4 scales evaluating intestinal syndrome and GvHD grade.

\section{Results}

When evaluating stool consistence according to Bristol scale as an index of GvHD therapy efficiency, we have observed complete clinical response by the D+120 after FMT in nine cases ( $47 \%$ with Bristol score of $\leq 4$ points), and nine patients (47\%) showed improved stool properties ( $>4$ points). In the placebo group, complete or partial response was revealed, respectively, in one (13\%), and four cases $(50 \%)$ on the D+120. Multiplex PCR of fecal microbiota has shown a different time course in FMT- and placebo-treated patients, when compared to their initial (pre-FMT) levels. Total bacterial mass and copy numbers of distinct microbial species exhibited sufficient increase after FMT. Such shifts were demonstrable on $\mathrm{D}+30$ for total microbial mass $(\mathrm{p}=0.002)$; Escherichia coli $(\mathrm{p}=0.001)$; Bacteroides fragilis group $(\mathrm{p}=0.05)$; Faecalibacterium prausnitzii $(\mathrm{p}=0.005)$. Meanwhile, the numbers Lactobacillus spp., and Bacteroides thetaiotaomicron, generally, were not changed over this time period. Moreover, in the control group (placebo) we have not found significant fecal microbiota changes against initial levels during 120 days monitoring period. Over 120 days of observation, we have also found some differences of the microbiota dynamics for the sub- 
groups with complete response and partial/no response: Bifidobacterium spp. $(\mathrm{p}<0.047)$, E.coli $(\mathrm{p}<0.00047)$, B. fragilis group $\left(\mathrm{p}=5.6 \times 10^{-5}\right)$, F.prausnitzii $(\mathrm{p}<0.0062)$.

\section{Conclusions}

1. Quantitative PCR of the major bacterial groups of gut microbiota, e.g., Bifidobacterium spp., E. coli, B. fragilis group, F. prausnitzii could be used as microbiological markers for evaluation of changing microbial landscape after FMT as a routine molecular biology technique. 2 . The genocopy counts of $B$. fragilis group correlate with clinical response in the patients with intestinal GvHD after HSCT, either with, or without FMT procedure.

\section{Keywords}

Graft-versus-host disease, fecal microbiota, transplantation, gut microbiome, Bacteroides fragilis, polymerase chain reaction, multiplex, next generation sequencing, $16 \mathrm{~S}$ rDNA gene.

\section{Introduction}

Fecal microbiome contains hundreds types of bacteria, with only minority of, mostly, aerobic gut bacteria having been detectable in bacteriological cultures. However, conventional microbiological cultures are able to detect only a limited number of aerobic and, to lesser degree, anaerobic bacteria in fecal samples. In this respect, a gene-specific DNA diagnostics, e.g., multiplex PCR aimed for detection of potentially pathogenic microbes, is a more sensitive technique for detection and quantification of distinct microbial species and families at different microbiotes of human body [1].

Moreover, major bacterial classes and families became available for studies and comparisons, due to development of the next-generation sequencing (NGS). Bacteroides and Clostridia comprise the majority of normal intestinal flora as suggested by several NGS studies performed in different parts of the world $[2,3]$. These microbial types are susceptible to massive antibiotic treatment which is usually applied in immunocompromised patients after bone marrow transplantation [4].

Still there are no generally approved reference biodiversity values, or marker microorganisms for assessment of gut microbiome in immunocompromised patients following severe cytostatic and antimicrobial therapy. Severe intestinal affection after allogeneic hematopoietic stem cell transplantation (allo-HSCT) is a useful clinical model for evaluation of gut microbiome shifts and its correction after fecal microbiota transplantation (FMT) [5]. An FMT protocol for clinical trials in severe graft-versus-host disease (GvHD) was applied quite recently [6].

Despite numerous clinical studies on FMT, there are only few bacterial markers for monitoring its efficiency. Appropriate guidelines are limited to bacteriological screening of the third-party donors of fecal transplants [7]. To our knowledge, there are no clear recommendations on screening of fecal microbiota in the patients. Except of time- and labor-consuming NGS analysis, some multiplex PCR-based approaches may be used that detect distinct gut pathogens $[8,9]$. A quite recent approach is based on determination of relative proportions for the dominant phyla in human gut microbiome [10].
To evaluate real biodiversity of intestinal microbiome, most recent works are performed by sequencing of $16 \mathrm{~S}$ rRNA fragments from multiple bacterial species, with subsequent detection of species-specific genes. The results of NGS assays provide a big number of $16 \mathrm{~S}$ rRNA nucleotide sequences which correspond to relative representation of distinct bacterial classes in the given sample. The best reliable data derived from NGS analysis concern biological diversity for big taxonomic classes of microbiota, down to the family level. More exact species-specific diagnostics is less robust, due to only marginal interspecies differences in nucleotide sequences detectable by the current NGS technique.

Therefore, some more simple and cost-effective microbial markers are required for evaluation and screening of human microbiota after massive antibiotic therapy and in the course of gut recolonization. Hence, the aim of our study was a search for microbial species detectable by molecular biology techniques that could correlate with clinical results of FMT performed in severe resistant GvHD after allo-HSCT.

\section{Patients and methods}

The prospective single-center study included 27 patients at the age of 1 to 52 years old (median, 25 years) after alloHSCT at the Raisa Gorbacheva Memorial Research Institute of Pediatric Oncology, Hematology and Transplantation over a period of 2017 to 2019 (Table 1). The main group included 19 post-HSCT patients who developed acute intestinal GvHD. All the patients were in remission state for their primary disease. These patients received FMT due to severe GvHD resistant to standard treatment. The inclusion criterion was steroid-refractory acute or chronic GvHD (overlap-syndrome) accompanied by intestinal affection. Intestinal GvHD has been confirmed by pathological examination of colonic mucosa biopsies. FMT was performed at a median of 110 (37-909) days post-HSCT. The comparison group with similar GvHD symptoms included eight patients who received placebo preparations instead of FMT applied on a median of 56 (34-120) days after HSCT.

Antimicrobial prophylaxis was canceled 3 days before and during TFM treatment. Systemic antibacterial drugs were administered by common clinical indications (local infection, septicemia) to 8 patients (37\%) before FMT, and in 18 
cases (95\%), after the procedure. Seven placebo-treated patients out of $8(88 \%)$ were also exposed to systemic antimicrobial therapy. The patients with proven intestinal affection with HHV6 or EBV herpes viruses received gancyclovir: 11 (58\%) in FMT-treated, 8 (100\%) in the placebo group.

All the patients received immunosuppressive therapy as the first-line GvHD treatment, by means glucocorticosteroids (methylprednisolone, $1 \mathrm{mg} / \mathrm{kg} / \mathrm{d}$ ). The second-line therapy was performed with Ruxolitinib at the dose of $10-15 \mathrm{mg} / \mathrm{d}$ (for children $0.25 \mathrm{mg} / \mathrm{kg} / \mathrm{d}$ ). The patients underwent clini$\mathrm{cal}$ and laboratory screening at the following terms: before FMT/placebo treatment D -1-3, D+3, D+16, D+30, D+60, and D+120 after FMT. The next day after last FMT was considered D+1. Primary endpoints were determined on the D+30 following FMT or placebo administration.

\section{Table 1. Clinical characteristics of the FMT patients}

\begin{tabular}{|c|c|c|}
\hline Parameter & FMT group & Placebo group \\
\hline Total patient number, $\mathrm{n}$ & 19 & 8 \\
\hline Age, years, median (ranges) & $22(3-49)$ & $27(1-52)$ \\
\hline Gender, $\mathrm{m} / \mathrm{f}, \mathrm{n}(\%)$ & $.10 / 9(53 / 47)$ & $.3 / 5(38 / 62)$ \\
\hline \multicolumn{3}{|l|}{ Diagnosis, n (\%) } \\
\hline Acute lymphoblastic leukemia & $5(26)$ & $4(50)$ \\
\hline Acute myeloblastic leukemia & $5(26)$ & $1(13)$ \\
\hline Myelodysplastic syndrome & $3(16)$ & $1(13)$ \\
\hline Non-Hodgkin lymphoma & $1(5)$ & $1(13)$ \\
\hline Hodgkin lymphoma & $1(5)$ & $0(0)$ \\
\hline Multiple myeloma & $1(5)$ & $0(0)$ \\
\hline Chronic myeloid leukemia & $1(5)$ & $1(13)$ \\
\hline Inherited diseases & $2(10)$ & $0(0)$ \\
\hline \multicolumn{3}{|l|}{ Conditioning therapy, $\mathbf{n}(\%)$} \\
\hline Fludarabine+Busulfan & $11(58)$ & $7(88)$ \\
\hline Fludarabine+Melphalan & $4(21)$ & $0(0)$ \\
\hline Fludarabine+Bendamustin & $3(16)$ & $0(0)$ \\
\hline Fludarabine+Cyclophosphamide & $1(5)$ & $1(13)$ \\
\hline \multicolumn{3}{|l|}{ HSCT type, n (\%) } \\
\hline Allogeneic unrelated & $11(58)$ & $1(13)$ \\
\hline Allogeneic related & $0(0)$ & $1(13)$ \\
\hline Haploidentical & $8(42)$ & $6(74)$ \\
\hline \multicolumn{3}{|l|}{ GvHD prophylaxis, n (\%) } \\
\hline Cyclophosphamide+Tacrolimus+MMF & $11(58)$ & $4(50)$ \\
\hline Cyclophosphamide+Tacrolimus+Sirolimus & $2(10)$ & $3(37)$ \\
\hline Bendamustin+Tacrolimus+MMF & $3(15)$ & $0(0)$ \\
\hline Cyclophosphamide+Tacrolimus+ATG & $2(10)$ & $1(13)$ \\
\hline T-Depletion & $1(5)$ & $0(0)$ \\
\hline \multicolumn{3}{|l|}{ GvHD Therapy at FMT, n (\%) } \\
\hline Glucocorticosteroids+Ruxolitinib & $6(32)$ & $5(63)$ \\
\hline Glucocorticosteroids+Sirolimus & $2(10)$ & $0(0)$ \\
\hline Glucocorticosteroids+Ruxolitinib+Sirolimus & $9(47)$ & $3(37)$ \\
\hline Glucocorticosteroids+Ruxolitinib+Etanercept+ECP+Mesenchymal cells & $2(10)$ & $0(0)$ \\
\hline \multicolumn{3}{|l|}{ Intestinal GvHD, n (\%) } \\
\hline Acute & $15(79)$ & $8(100)$ \\
\hline Chronic (overlap syndrome) & $4(21)$ & $0(0)$ \\
\hline \multicolumn{3}{|l|}{ Intestinal GvHD grade, n (\%) } \\
\hline Grade 1-2 & $9(47)$ & $3(38)$ \\
\hline Grade 3-4 & $10(53)$ & $5(62)$ \\
\hline
\end{tabular}


Routine laboratory studies at the ICU included daily blood cell and differential leukocyte counts, routine serum biochemistry, serum markers of inflammation (procalcitonine, C-reactive protein). In cases of acute intestinal syndrome, the aerobic microbial cultures of stool samples were routinely seeded, and C.difficile toxins A and B were checked by a simple immune chromatography test (VEDALAB, France).

In four cases $(21 \%)$, the fecal transplant donation was performed from related donors (mother, 1; father, 2; brother, 1). FMT from unrelated donors was carried out in 15 patients.

Fecal transplants were administered by the following methods: via gastroduodenoscope, in 3 patients (16\%); via nasointestinal catheter, in 7cases ( 3 TFM+ and 4 placebo); 13 patients (68\%) ingested gelatin capsules with frozen microbiota. Placebo capsules were used in 4 patients (50\%).

The single-center prospective study "Treatment of children and adult patients with inflammatory and infectious gut lesions after allogeneic transplantation of hematopoietic stem cells using transplantation of normal human microbiota" was approved by the Local Review Board at the First I. Pavlov Saint-Petersburg State Medical University №192 от 30.01.2017. The trial was performed in accordance with Good Clinical Practice and Declaration of Helsinki, i.e., full awareness of the study purpose, procedures and possible adverse effects from treatment, as stated by appropriate written informed consent signed by each patient or his (her) competent relative.

\section{Fecal microbiota encapsulation procedure}

Preparation of fecal transplants and their storage at $-80^{\circ} \mathrm{C}$ was performed at the specialized microbiological laboratory. In brief, the donor material was supplemented with $10 \%$ glycerol and 50\% sterile dextrose syrup (v/v), then homogenized with a disposable blender. The material, placed on ice, was then packed up in solid Coni-Snap ${ }^{\circledR}$ Size 0 gelatin capsules using the ProFiller 1100 device. The bar-coded capsules were placed into individual sterile containers. The fecal transplants (FT) were transferred to a freezing chamber $\left(-80^{\circ} \mathrm{C}\right)$ and stored until use. The capsules were administered at a dose of 10 (3-15) capsules for 2 or 3 subsequent days. The total dose per single TFM course was $22 \mathrm{~g}$ (30 capsules) corresponding to $0.41(0.29-1.67 \mathrm{~g} / \mathrm{kg}$ body mass), independent on age and weight of the subjects.

The patients from comparison group were treated with $5 \mathrm{~mL}$ of $0.9 \%$ physiological saline delivered during diagnostic gastroscopy, or frozen capsules with physiological saline.

Table 2. Reference values for different microbial species detected by multiplex real-time PCR kit (Colonoflor-16)

\begin{tabular}{|l|l|l|}
\hline № & Parameter & Reference interval (copies/mL) \\
\hline 1 & Total bacterial mass & $10^{11}-10^{13}$ \\
\hline 2 & Lactobacillus spp. & $10^{7}-10^{8}$ \\
\hline 3 & Bifidobacterium spp. & $10^{9}-10^{10}$ \\
\hline 4 & Escherichia coli & $10^{7}-10^{8}$ \\
\hline 5 & Bacteroides fragilis group & $10^{9}-10^{12}$ \\
\hline 6 & Bacteroides thetaiotaomicron & Any amount $<10^{12}$ \\
\hline 7 & Faecalibacterium prausnitzii & $10^{8}-10^{11}$ \\
\hline 8 & Akkermansia muciniphila & Any amount $10^{12}$ \\
\hline 9 & Escherichia coli enteropathogenic & $<10^{4}$ \\
\hline 10 & Enterococcus spp. & $<10^{8}$ \\
\hline 11 & Proteus vulgaris / Proteus mirabilis & $<10^{4}$ \\
\hline 12 & Citrobacter spp. / Enterobacter spp. & $<10^{4}$ \\
\hline 13 & Parvimonas micra & Not detectable \\
\hline 14 & Candida spp. & $<10^{4}$ \\
\hline 15 & Clostridium difficile & $<10^{4}$ \\
\hline 16 & Clostridium perfringens & $<10^{4}$ \\
\hline 17 & Fusobacterium nucleatum & Not detectable \\
\hline 18 & Klebsiella oxytoca & $<10^{4}$ \\
\hline 19 & Klebsiella pneumoniae & $<10^{4}$ \\
\hline 20 & Salmonella spp. & Not detectable \\
\hline 21 & Shigella spp. & Not detectable \\
\hline 22 & Staphylococcus aureus & $<10^{4}$ \\
\hline
\end{tabular}


Table 3. Gene-specific primers for detection of distinct microbes in fecal material (Colonoflor test system)

\begin{tabular}{|c|c|c|}
\hline Detected parameters & Forward (F) primers, reverse (R) primers and fluorescent probes (Z) & Gene specification \\
\hline \multirow{3}{*}{ Total bacterial mass } & Tot_F TCCTACGGGAGGCAGCAGT & \multirow{3}{*}{165 rRNA } \\
\hline & Tot_R GGACTACCAGGGTATCTAATCCTGTT & \\
\hline & Tot_Z 6'FAM-CGTATTACCGCGGCTGCTGGCAC-BHQ-1 & \\
\hline \multirow{3}{*}{ Bifidobacterium spp. } & Lacto_2 CCATTGTGGAAGATTCCCTACTGC & \multirow{3}{*}{165 rRNA(2-5) } \\
\hline & Lacto_Z 6'FAM-ATCGGCCACATTGGGACTGAGAC-BHQ-1 & \\
\hline & Bif_F GCGTGCTTAACACATGCAAGTC & \\
\hline \multirow{3}{*}{$\begin{array}{l}\text { Bacteroides fragilis } \\
\text { group }\end{array}$} & Bif_R CACCCGTTTCCAGGAGCTATT & \multirow{3}{*}{165 rRNA(7) } \\
\hline & Bif_Z 6'FAM-TCACGCATTACTCACCCGTTCGCC-BHQ-1 & \\
\hline & Bac_frag_F CGGAGGATCCGAGCGTTA & \\
\hline \multirow{3}{*}{$\begin{array}{l}\text { Faecalibacterium } \\
\text { prausnitzii }\end{array}$} & Bac_frag_R CCGCAAACTTTCACAACTGACTTA & \multirow{3}{*}{ 16S/ rRNA } \\
\hline & Bac_frag_Z 6'FAM-CGCTCCCTTTAAACCCAATAAATCCGG-BHQ-1 & \\
\hline & Fprau_F CCATGAATTGCCTTCAAAACTGTT & \\
\hline
\end{tabular}

\section{Laboratory screening of gut microbiota}

Semi-quantitative assessment of fecal microbiota profile was performed with real-time PCR technique using commercial Colonoflor-16test system (Alpha-Lab, Saint Petersburg, Russia). Total bacterial mass, as well most represented microbial species, including strictly anaerobic species, could be detected by this DNA-based technique (Table 2). A set of gene-specific primers is used in this test kit, exploiting the differences in $16 \mathrm{~S}$ rDNA sequences (see Table 3 ).

The same fecal DNA samples were used for detailed $16 \mathrm{~S}$ rDNA sequencing by means of NGS technique, as elsewhere described [11]. The serial microbiome sequencing procedure was carried out with Illumina ${ }^{\text {Tw }}$ HiSeq 2500 system.

\section{Clinical evaluation}

Clinical examination of the patients along the observation period until $\mathrm{D}+120$ was performed by the well-validated scales: GvHD severity score [12]; evaluation of clinical response of GvHD patients to therapy [13]; Bristol scale of stool [14].

All the patients (or their parents) filled a special diary with notices on their actual daily condition and severity of distinct symptoms by scoring the adverse treatment effects, according to the Common Terminology Criteria for Adverse Events Version 5.0 (CTCAE), version 5.0 of November 27 2017) [15], as follows: anorexia (1-5 points), nausea (1-3 points), lower intestinal bleeding (1-5 points). Pain syndrome (abdominal pains) was evaluated by the 10-point visual analogue scale for adults and children (VAS), according to WHO criteria $[16,17]$. Number of defecations, daily volumes of diarrhea and vomiting were registered. The stool properties were evaluated according to the Bristol scale (1 to 7 points).

Aiming for a more objective evaluation of clinical response, the patients from main group were divided in two subgroups, i.e., patients who showed full clinical response (CR), and those who responded only partially or lacked any positive response (PLR). These and other parameters were introduced into a common database.
The stool consistence was evaluated by the seven-point Bristol scale [14] (Lewis, Heaton, 1997). Volumes of water lost with stool and vomiting was also registered. A validated toxicity scale was used to evaluate bloody and mucous admixtures, loss of appetite, and other side effects (CTCAE Version 5.0 Published: November 27, 2017), using a 4-point scoring of its intensity ( 0 , the symptom absent; 1 , mild degree or periodic; 2 , intermediate (often); 3 , severe (permanent), requiring proper therapy). To evaluate abdominal pain, a 10-point VAS was applied $[16,17]$.

To specify rates of clinical response a, we classified the patients in 2 groups, i.e., the FMT outcomes were classified as the main group with complete response (CR), partial response (PR), or treatment failure (NR) in the patients. Full response was registered by 2 criteria, i.e., gut GvHD improvement (stool volume $<10 \mathrm{~mL} / \mathrm{kg} /$ day, absence of abdominal pains and bloody stool, no signs of gut paresis), and stool consistence of $<4$ points at Bristol scale should be registered. Partial response was documented in cases of complete response for intestinal GvHD, and stool consistence of $>4$ points by Bristol scale (stool volume $>10 \mathrm{ml} / \mathrm{kg} /$ day). Absence of clinical response was documented if no complete recovery for intestinal GvHD, along with liquid stool (Bristol scale, 6 to 7 points, daily stool volume $>10 \mathrm{~mL} / \mathrm{kg}$ weight).

On the days before FMT/placebo administration, and by the days $+3,+16,+30,+60,+120$ after FMT, the mean sum values for preceding time period were calculated, beginning from the next day after last control point until the target point of the study. When analyzing clinical results, the last day of TFM treatment was assumed as day 0 for the observation period.

\section{Statistical evaluation}

All clinical and laboratory data obtained during the follow-up examinations were analyzed with $\mathrm{R}$ programming language v.3.6.2 in Rstudio v. 1.2.5033. Shannon index for $16 \mathrm{~S}$ sequencing results was calculated as follows:

$$
S=\sum_{k=1}^{n} p_{i} \log _{2} p_{i}
$$


where $n$ is a number of detected bacterial groups, $p_{i}$, frequency of $i$-th group occurrence. Comparison of samples was performed with non-parametric statistical methods: Wilcoxon test for two-sample comparisons, and Kruskal-Wallis test for three-sample comparison. Visualization was performed by means of R packages ggplot2 [18] and ggpubr [19].

\section{Results}

In the whole group of patients, some grade of response (disregarding Bristol scale) was achieved in 23 patients (85\%), at $\mathrm{D}+120$, including 18 cases after FMT (95\%), and 5 place- bo-treated patients $(63 \%)(\mathrm{p}=0.0646)$. Whole response was achieved in 16 patients (84\%) after FMT, versus in 5 cases (63\%) from placebo group $(\mathrm{p}=0.3191)$. One patient deceased without response to FMT (5\%) versus 3 patients (38\%) in the placebo group.

When evaluating clinical response to GvHD therapy, with regard of stool consistence by Bristol scale, we observed whole clinical response 120 days after FMT in 9 cases $(47 \%$ with Bristol score of $\leq 4$ points), and 9 patients (47\%) showed improvement stool consistence ( $>4$ points). In the placebo group, a complete or partial response was revealed, respectively, in $1(13 \%)$ and $4(50 \%)$ of the patients by the day +120 .

A

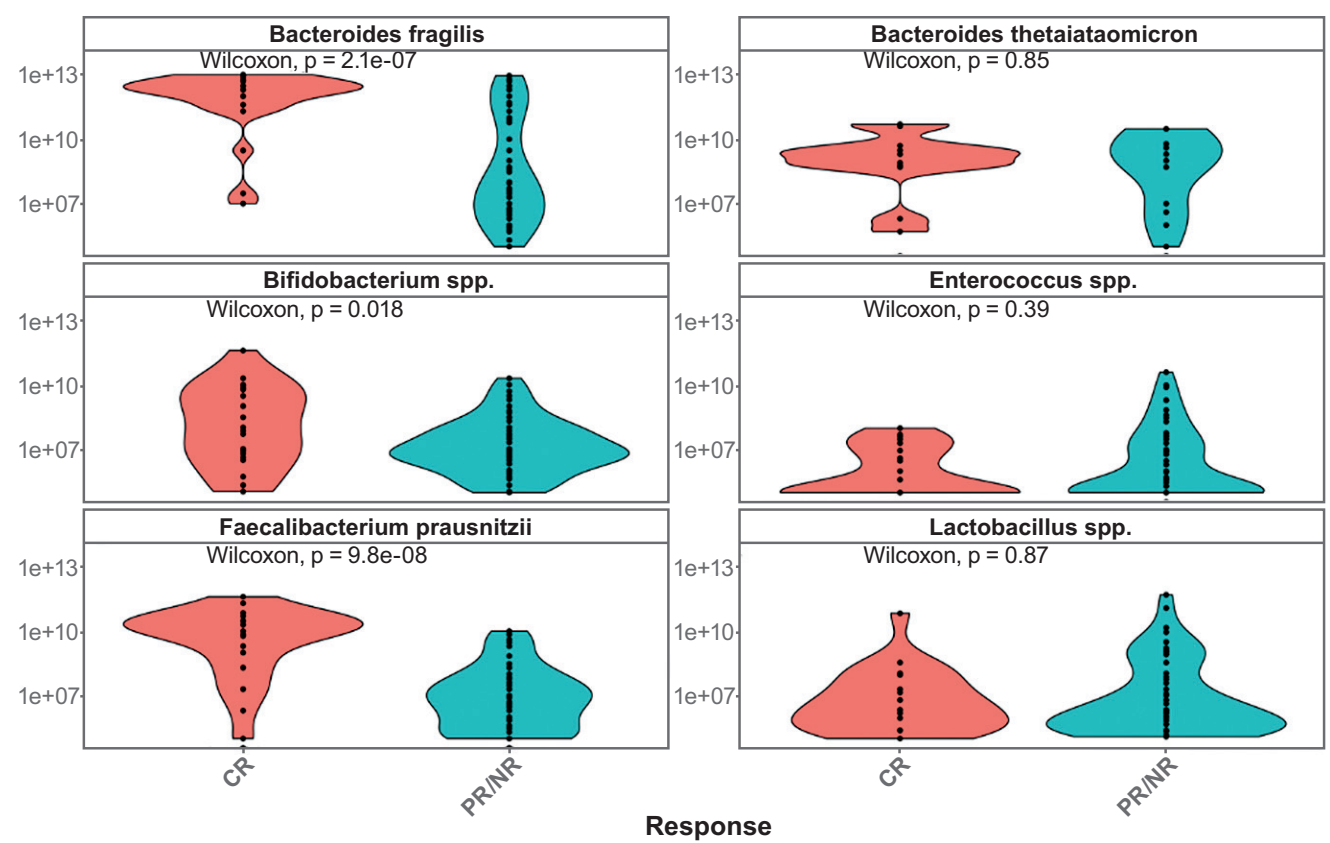

B

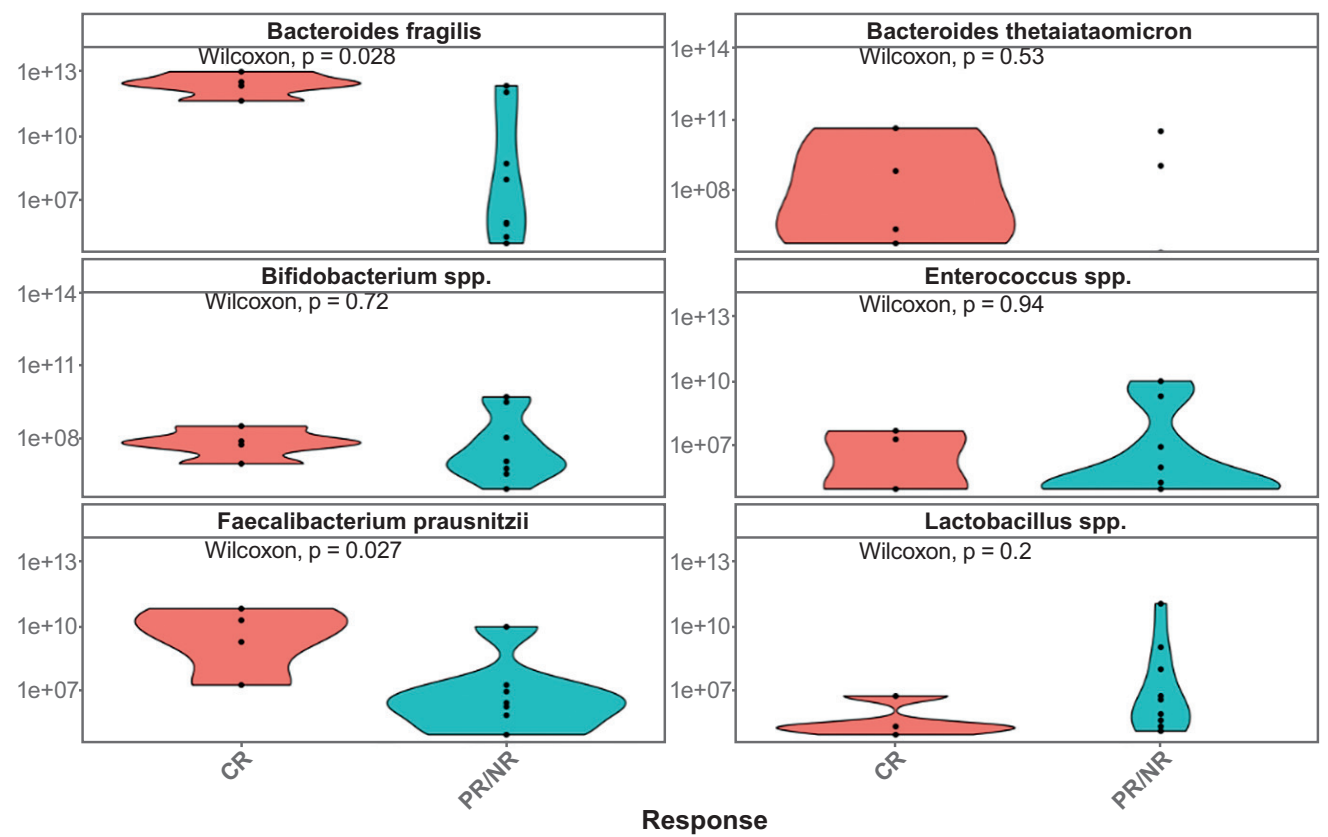

Figure 1. Relative contents of dominant fecal microbial species in the total set of samples from all the study terms (A), and on day +30 of observation (B) in the patients with complete response (red), partial/absent response (blue) including the placebo group. Abscissa, type of response after FMT. Ordinate, number of genocopies, $\log _{10}$ per standard sample (0.1 g) 
Table 4. Significance of differences ( $p$ values) between initial (pre-TFM/placebo) and post-FMT levels of certain microorganisms in fecal microbiota of total patient group (19 FMT cases and 8 placebo-treated patients)

\begin{tabular}{|l|l|l|l|l|l|l|l|}
\hline Days after FMT/Placebo & & $\mathrm{D}+3$ & $\mathrm{D}+16$ & $\mathrm{D}+30$ & $\mathrm{D}+60$ & $\mathrm{D}+90$ & $\mathrm{D}+120$ \\
\hline \multirow{3}{*}{ Total bacterial mass } & FMT & 0.002 & 0.001 & 0.002 & 0.036 & 0.072 & 0.038 \\
\cline { 2 - 8 } & Placebo & 0.62 & 0.268 & 0.343 & 0.412 & 0.109 & 0.315 \\
\hline \multirow{3}{*}{ Lactobacillus spp. } & FMT & 0.4 & 0.141 & 0.903 & 0.526 & 1 & 0.281 \\
\cline { 2 - 8 } & Placebo & 0.902 & 0.876 & 0.432 & 0.927 & 0.648 & 0.927 \\
\hline \multirow{3}{*}{ Bifidobacterium spp. } & FMT & 0.107 & 0.036 & 0.001 & 0.239 & 0.288 & 0.016 \\
\cline { 2 - 8 } & Placebo & 1 & 0.073 & 0.638 & 0.788 & 0.164 & 0.412 \\
\hline \multirow{3}{*}{ E.coli } & FMT & 0.000 & 0.007 & 0.001 & 0.004 & 0.048 & 0.000 \\
\cline { 2 - 8 } & Placebo & 0.165 & 0.876 & 0.53 & 0.537 & 0.648 & 0.648 \\
\hline \multirow{3}{*}{ B. fragilis } & FMT & 0.000 & 0.005 & 0.05 & 0.272 & 0.05 & 0.033 \\
\cline { 2 - 8 } & Placebo & 0.383 & 0.149 & 0.106 & 0.527 & 0.788 & 0.315 \\
\hline \multirow{3}{*}{ B.thetaiataomicron } & FMT & 0.007 & 0.109 & 0.109 & 0.662 & 0.745 & 0.461 \\
\cline { 2 - 8 } & Placebo & 0.71 & 0.755 & 0.755 & 0.755 & 0.755 & 0.755 \\
\hline \multirow{2}{*}{ F.prausnitzii } & FMT & 0.000 & 0.002 & 0.005 & 0.01 & 0.003 & 0.000 \\
\cline { 2 - 8 } & Placebo & 0.805 & 0.639 & 0.53 & 0.648 & 1 & 0.648 \\
\hline
\end{tabular}

Note: The differences significant at $\mathrm{P}<0.05$ are shown in bold-face type.

Multiplex PCR of fecal microbiota has shown a different time course in FMT- and placebo-treated patients, when compared to their initial (pre-FMT) levels. Total bacterial mass and copy numbers of distinct microbial species exhibited sufficient increase in the patients with complete clinical response (Fig. 1). In patients with full clinical response after FMT, or placebo, we have detected increased amounts of some major microbial groups by means of Colonoflor testing, i.e., Bacteroides fragilis group, Bifidobacterium spp., Faecalibacterium prausnitzii, along with decrease in Enterococcus spp. and Lactobacillus spp.

E.g., such shifts in total group of samples were demonstrable for B.fragilis group $\left(\mathrm{p}=2.1 \times 10^{-7}\right)$; F.prausnitzii $\left(\mathrm{p}=9.8 \times 10^{-8}\right)$ during the observation terms (Fig. 1A). Similar increase in B.fragilis group $(\mathrm{p}=0.028)$, and F.prausnitzii $(\mathrm{p}=0.027)$ was detectable by the $\mathrm{D}+30$ in FMT-treated or placebo patients (Fig. 1B)

Moreover, a stable and significant increase of B.fragilis group and F.prausnitzii was revealed since early terms in FMT-treated patients compared to placebo-treated patients (Table 4).

Meanwhile, the numbers of Enterococcus, Lactobacillus spp., and Bacteroides thetaiotaomicron, generally, were not changed over this time period (Table 4). In the control group (placebo) we have not found significant changes of fecal microbiota against initial levels over 120 days of monitoring.
Mean values of Bifidobacterium spp., E.coli, B.fragilis group and F.prausnitzii were significantly different for the studied groups ( $\mathrm{p}<0.003 ; \mathrm{p}<0.012 ; \mathrm{p}<0.016 ; \mathrm{p}<0.12$, respectively), as seen in Fig. 2. We have also found some differences of the microbiota dynamics for the subgroups with complete response, partial/no response: Bifidobacterium spp. $(\mathrm{p}<0.047)$, E.coli $(\mathrm{p}<0.00047)$, B.fragilis gr. $\left(\mathrm{p}<5.6 \times 10^{-5}\right)$, F.prausnitzii $(\mathrm{p}<0.0062)$.

In the placebo group, we did not detect any cases of C.difficile-associated infections. Meanwhile, three cases of C.difficile infection were detected in the FMT group. However, both $\mathrm{A}$ and $\mathrm{B}$ toxins of $C$.difficile became negative by day $+16,+30$ and $+45 \mathrm{~s}$ after FMT.

Hence, relative contents of B.fragilis group in fecal microbiota was selected as a bacterial marker increased upon recolonization, due to sufficient difference between complete and no/partial response to the FMT $\left(\mathrm{p}=2.1 \times 10^{-7}\right)$, and pronounced dynamics of changes $\left(\mathrm{p}=5.6 \times 10^{-5}\right)$ over 120 days of observation. Therefore, was selected for further studies, i.e. search for correlations with NGS results on Bacteroidia class.

Correlations between the ratios of specific microbial DNA extracted from fecal samples determined by the 16S rRNA NGS technique were assessed at phylogenetic levels of Bacteroidetes (Phylum), Bacteroidia (Class), and Bacteroidales (Order). Among all microbial specificities detectable by quantitative PCR (Colonoflor test set), only Bacteroides 


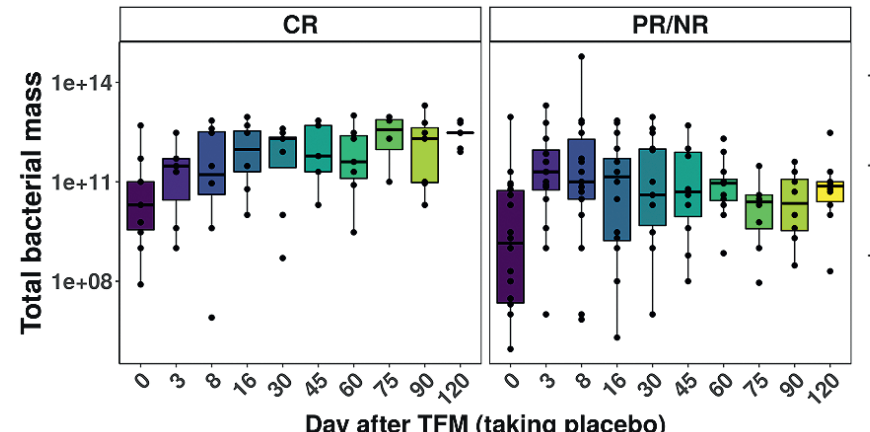

Day after TFM (taking placebo)
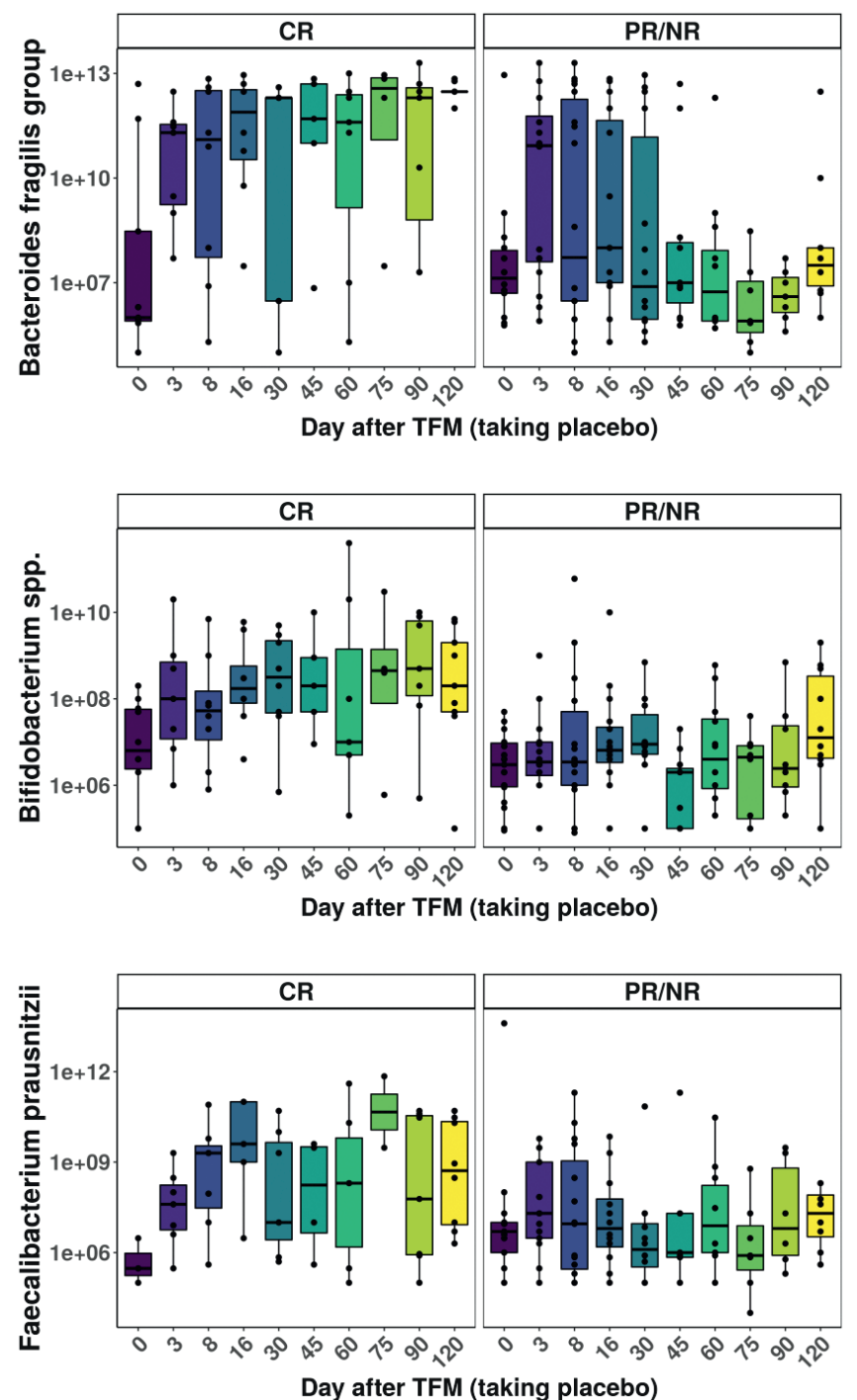

Day after TFM (taking placebo)

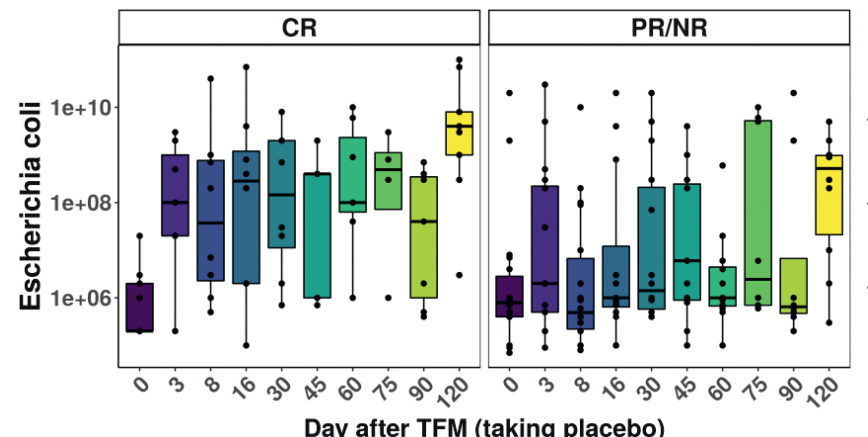

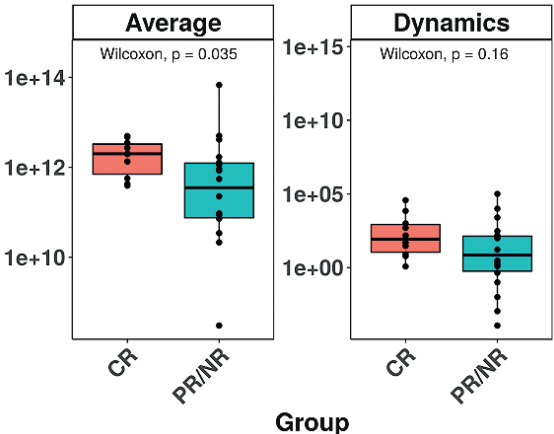

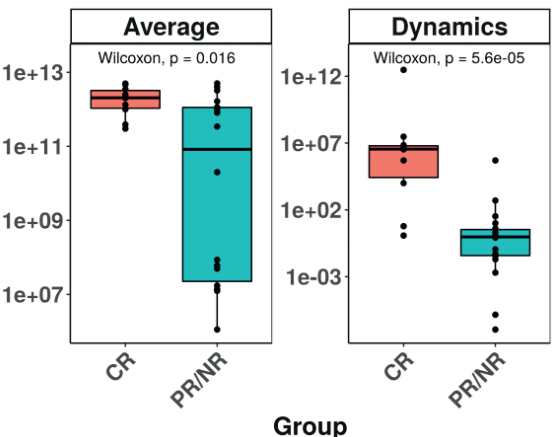

Group
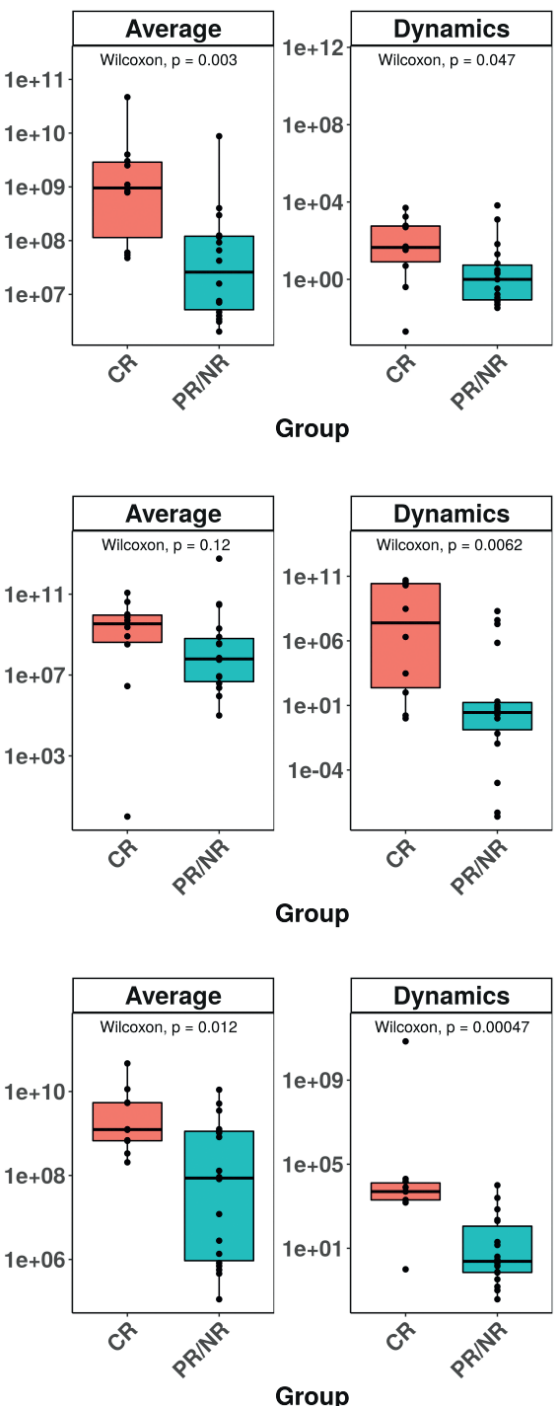

Figure 2. Time-dependent changes of total bacterial mass and four selected bacterial classes are presented over 120 days of observation. Abscissa, subgroups of patients; Ordinate, number of genocopies, $\log _{10}$ per standard sample (0.1 g) Note: the groups with different response include FMT- and placebo-treated patients. 
fragilis group showed strong correlation with the ratios of Bacteroidetes phylum and Bacteroidia class revealed NGS approach. When applying NGS technique for detection of gut bacteria, we revealed high correlation only between the general types of bacteroides, i.e. phylum (Bacteroidetes); class (Bacteroidia); order (Bacteroidales); family (Bacteroidaceae), genus (Bacteroides) (Table 5).

B. fragilis contents in fecal microbiota from healthy donors proved to be significantly higher than in the patients with GvHD before FMT (Table 6), thus potentially requiring enhancement of these microorganisms in the patients after HSCT with immune complications. After FMT, the median levels of B.fragilis group are sufficiently increasing in parallel to complete clinical response, being, however, at lower levels in cases with partial or zero response.

Hence, the evaluation of B.fragilis group using real-time PCR, generally correlates with data on broader Bacteroides class obtained by 16 SrRNA sequencing performed by much more complex and costly NGS technique. Meanwhile, multiplex PCR allows to get semi-quantitative results which could be used for routine monitoring of gut dysbiosis and its recovery.

In this series, $\mathrm{D}+30$ proved to be the most informative time point for discerning differences between FMT and placebo-treated patients. I.e., on D+30 (a control point of study), we have found an increase over the D0 ratios in Bacteroidetes phylum; Bacteroidia (Class); Bacteroidales (Order) when studied by NGS approach. A strong correlation was found at all the time points with copy numbers of B.fragilis (PCR technique), as shown in Fig. 3.
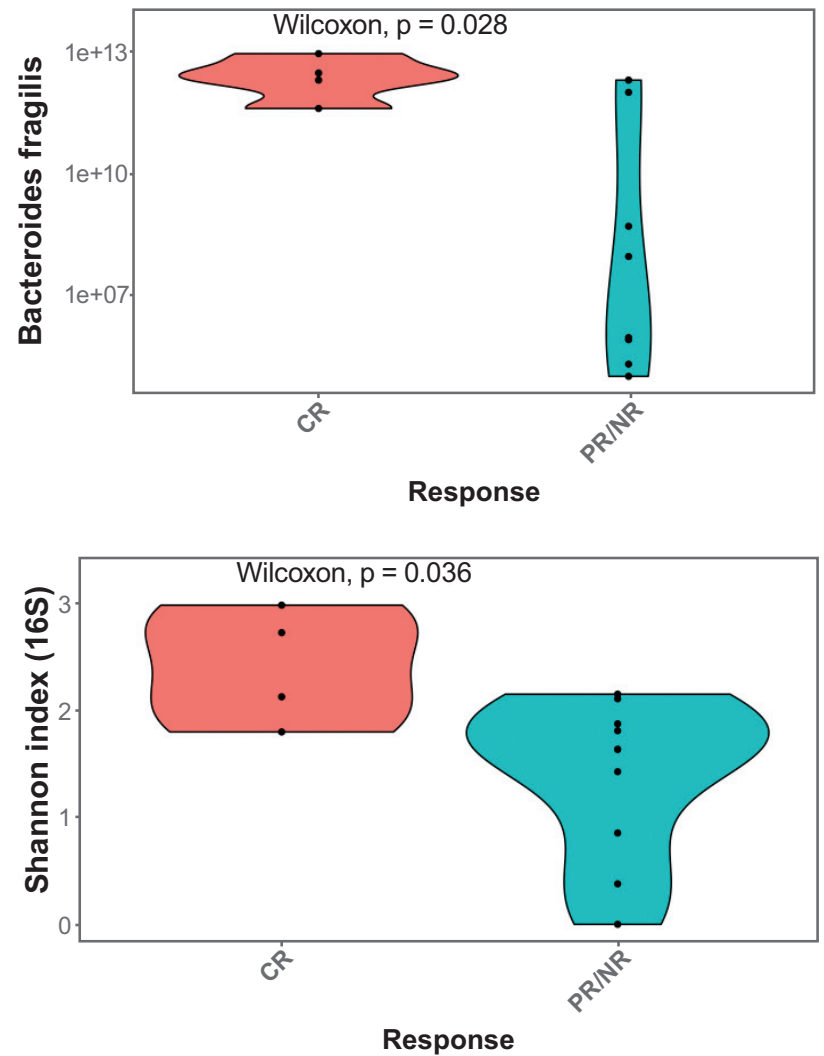

Figure 3. Parallel changes of B.fragilis copy numbers (multiplex PCR) and Shannon index of genomic bacterial diversity determined by 165 rRNA sequencing for the groups with complete response (CR) versus partial/ lacking response after FMT or placebo on D+30

Table 5. Correlations between the main types of Bacteroidetes and B.fragilis group determined by NGS approach

\begin{tabular}{|l|l|l|l|l|c|}
\hline \multicolumn{6}{|c|}{ Bacteroides types revealed by NGS (n=38 samples) } \\
\hline $\begin{array}{l}\text { Type } \\
\text { Bacteroidetes }\end{array}$ & $\begin{array}{l}\text { Class } \\
\text { Bacteroidia }\end{array}$ & $\begin{array}{l}\text { Order } \\
\text { Bacteroidales }\end{array}$ & $\begin{array}{l}\text { Family } \\
\text { Bacteroidaceae }\end{array}$ & $\begin{array}{l}\text { Genus } \\
\text { Bacteroides }\end{array}$ & $\begin{array}{l}\text { Species } \\
\text { B.fragilis }\end{array}$ \\
\hline \multicolumn{5}{|c|}{ Correlation quotients and their significance } \\
\hline 0.742 & 0.744 & 0.744 & 0.762 & 0.772 & 0.455 \\
$<0.000$ & $<0.000$ & $<0.000$ & $<.000$ & $<.000$ & 0.004 \\
\hline
\end{tabular}

Table 6. B.fragilis contents in the fecal microbiota samples ( $\log _{10}$ of genocopy numbers) in healthy donors and patients with differential response to FMT

\begin{tabular}{|c|c|c|c|}
\hline Groups of samples & Healthy donors & $\begin{array}{l}\text { Patients } \\
\text { with complete response to FMT }\end{array}$ & $\begin{array}{c}\text { Patients } \\
\text { with partial/zero response }\end{array}$ \\
\hline \multicolumn{4}{|c|}{ Before FMT } \\
\hline Maximal & $5.00 \mathrm{E}^{\wedge} 12$ & $9.00 \mathrm{E}^{\wedge} 12$ & $1.00 \mathrm{E}^{\wedge} 08$ \\
\hline Median & $2.00^{\wedge} 12$ & $2.00 E^{\wedge} 07$ & $4.50 \mathrm{E}^{\wedge} 06$ \\
\hline Minimal & $9.00 \mathrm{E}^{\wedge} 10$ & $7.00 \mathrm{E}^{\wedge} 05$ & $0.00 \mathrm{E}^{\wedge} 00$ \\
\hline \multicolumn{4}{|c|}{30 days after FMT } \\
\hline Maximal & - & $9.00 \mathrm{E}^{\wedge} 12$ & $4.00 \mathrm{E}^{\wedge} 12$ \\
\hline Median & - & $2.00 \mathrm{E}^{\wedge} 12$ & $9.00 \mathrm{E}^{\wedge} 07$ \\
\hline Minimal & - & $9.00 \mathrm{E}^{\wedge} 05$ & $9.00 \mathrm{E}^{\wedge} 05$ \\
\hline
\end{tabular}


The numbers of fecal B.fragilis genocopies in all the patients (FMT and placebo) with complete response were increased on $\mathrm{D}+30$, and differed from the groups with partial/zero response after FMT procedure, or after placebo treatment (Fig. 3).

We have revealed a statistically significant correlation between the Shannon index (16 S rRNA sequencing) and B.fragilis levels (multiplex) PCR in the patients after FMT and/or placebo, either with complete response (CR), being significant at $\mathrm{p}=0.028$, or $\mathrm{partial} /$ absent response $(\mathrm{PR} / \mathrm{NR})$, at $\mathrm{p}=8 \times 10^{-4}$ (Fig. 4).

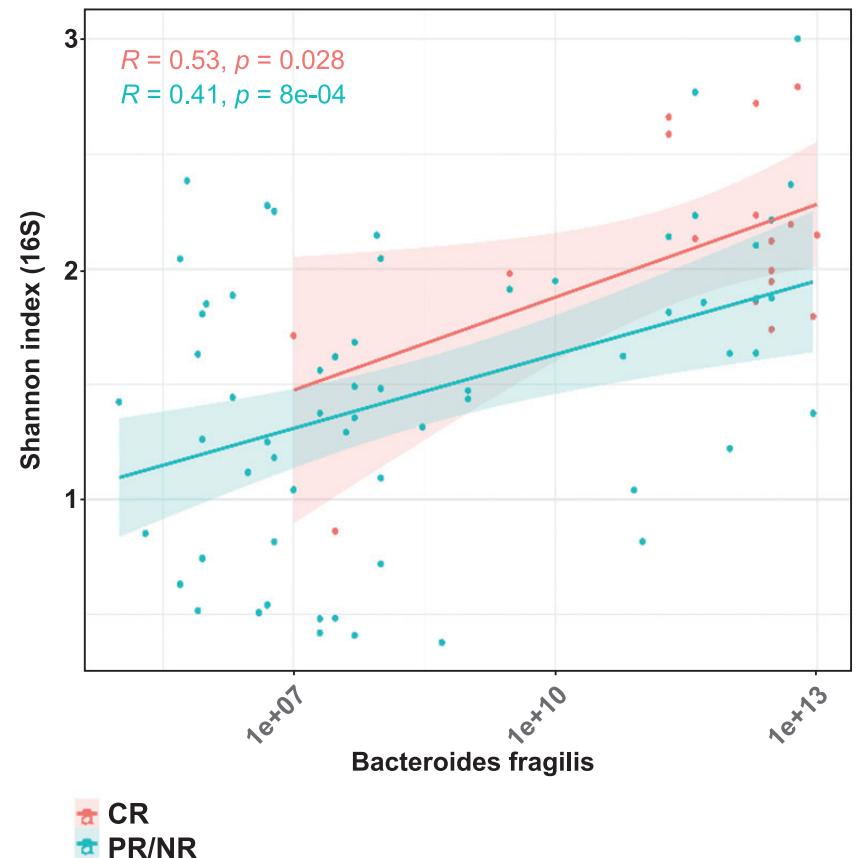

Figure 4. Correlations between fecal Bacteroides fragilis contents (abscissa), and Shannon microbial diversity index (ordinate) in the patients following FMT and/or placebo with complete or partial/absent clinical response at different observation terms. Complete clinical response to FMT: red points; partial or absent effect: blue points

Hence, on the basis of B.fragilis contents in fecal microbiota, its diversity (by Shannon index), and extent of clinical response for differently treated groups, we have obtained sufficient correlations between the subgroups with complete response, suboptimal response to FMT treatment, and placebo-treated patients.

\section{Discussion}

In this study we searched for microbiological correlates of clinical effect produced by FMT. We were able to compare the results of multiplex PCR technique and NGS gene analysis that were performed in parallel in the same fecal samples. Both molecular biology approaches proved to be effective when detecting shifts in gross classes of microbiota, e.g., Bacteroides, Clostridia and Enterobacter.

Using NGS approach, the proportions of some major microbiome classes are revealed, as follows: Bacteroidia, Clostridia, Gammaproteobacteria, Bacilli, Actinobacteria (Bifidobacterium $s p p$ ). The main classes discerned by the NGS approach are represented by distinct microbial species detected by Colonoflor multiplex PCR (Table 7).

As determined by next-generation sequencing and subsequent bioinformatics mining of resulting data bases for gut bacteria, we revealed high correlation only between gross types of bacteroides, i.e. phylum (Bacteroidetes); class (Bacteroidia); order (Bacteroidales); family (Bacteroidaceae), genus (Bacteroides) (Table 5). However, this correlation becomes much lower, when B.fragilis group is concerned, thus suggesting lesser precision of NGS diagnostics at the species level. Higher accuracy of the multiplex PCR for the B.fragilis group quantification could be explained by better specificity of appropriate primers, and due to presence of a reference gene marker for the total bacterial mass, thus allowing semi-quantitative determination.

To evaluate real biodiversity of intestinal microbiome, most recent works are performed by sequencing of $16 \mathrm{~S}$ rRNA fragments from multiple bacterial species, with subsequent detection of species-specific genes. The results of NGS assays provide a big number of $16 \mathrm{~S}$ rRNA nucleotide sequences which correspond to relative representation of distinct bacterial classes in the given sample. The best reliable data derived from NGS analysis concern biological diversity for big taxonomic classes of microbiota, down to the family level. More exact species-specific diagnostics is less robust, due to only marginal interspecies differences in nucleotide sequences detectable by the current NGS technique.

Therefore, some more simple and cost-effective microbial markers are required for evaluation and screening of human microbiota after massive antibiotic therapy and in the course of gut recolonization.

Table 7. Phylogenetic assignment of the bacteria revealed by 165 rRNA-based Colonoflor PCR system, and NGS approach (Illumina, MySeq)

\begin{tabular}{|l|l|}
\hline Bacterial classes discerned by NGS & Bacterial species detected by multiple qPCR \\
\hline Bacteroidia & Bacteroides fragilis group, Bacteroides thetaiotaomicron \\
\hline Clostridia & Faecalibacterium prausnitzii, C.difficile, C.perfringens \\
\hline Gammaproteobacteria>Enterobacteriales & $\begin{array}{l}\text { Klebsiella pneumoniae, Klebsiella oxytoca, Proteus, Enterobacter, Citrobacter, } \\
\text { Salmonella, Shigella, E.Coli }\end{array}$ \\
\hline Actinobacteria & Bifidobacterium spp. \\
\hline Others & Fusobacterium nucleatum, Parvimonas micra, Candida spp. \\
\hline
\end{tabular}


16S RNA gene polymorphism is a good method for control of ratios between the major classes of fecal microbiota. Moreover, drastic shifts of gut microbiota are revealed in several gut infections (mostly, C.difficile) and local immune affection, e.g., GvHD [20]. A conventional multiplex PCR approach allows performing a more specific, cheap and fast detection of major fecal microorganisms which is especially informative when using quantitative PCR (qPCR) after FMT, as shown in our study.

As seen from the presented data, one may recommend detection of the main bacterial groups (Bifidobacterium spp., Escherichia coli, B.fragilis group, Faecalibacterium prausnit$z i i)$ as potential markers for assessment of fecal microbiota shifts after FMT. It should be, however, noted that this correlation does not extend to other microbial groups (e.g., Lactobacillus spp., Citrobacter with absence of good correlation with $16 \mathrm{~S}$ rRNA sequencing for Lactobacillus spp. and Citrobacter, probably, due to suboptimal sensitivity of the given test system for Lactobacillus spp. $\left(<10^{5} \mathrm{CFU} /\right.$ sample $)$.

According to the qPCR data, the majority of microbial species sufficiently differed from the initial values on D+16 to D+30 after FMT, as seen for Bifidobacterium spp., Escherichia coli, B.fragilis group, F.prausnitzii. Therefore, one should presume engraftment of main fecal microorganisms after FMT over this period. Bacteroides compose $99 \%$ of normal microbiota, with quite important functional potential, being among promising probiotics [21].

Meanwhile, qPCR determination of B.fragilis group has shown a strong correlation with clinical response in the patients after FMT, thus allowing to consider this bacterial marker a potential laboratory correlate of efficient clinical response after FMT. An increase in Bacteroides quantities detected with qPCR and higher relative amounts found by means of NGS-based typing of 16S rDNA may, therefore, reflect engraftment of the major gut bacterial population. Decreased B.fragilis contents in the patients with partial or poor clinical response after D+30 post-FMT may be a non-engraftment marker, whereas increasing B.fragilis levels with a maximum about $\mathrm{D}+30$ are revealed in complete clinical response. Meanwhile, other findings presume pronounced changes in Clostridiales (e.g., Blautia) as possible index of microbiota maintenance, thus deserving their further pathogenetic significance [4]. E.g., the qPCR system for Clostridium spp. should be also applied for additional testing of the gut microbiota restoration, along with testing for pathogenic C.difficile toxins, as a negative prognostic marker.

Monitoring of gut bacterial markers to assess gut microbiota recovery may effectively improve clinical assessment in gastroenterology. The currently used clinical criteria are mostly indirect, including stool volume and quality, intestinal motility, fecal blood and calprotectin tests, thus requiring additional microbial markers aimed for quantitative evaluation of the disease state. Certain bacterial families may serve as semi-quantitative markers of the disease-associated shifts and recovery of the microbiota. We have shown that quantitative PCR of distinct gut microorganisms is quite available and cheaper option for routine follow-up of intestinal dysbiosis [22].
However, the 16S rDNA sequencing by means of NGS approach remain indispensable for research in the field, looking for novel markers of human microbiota in health and disease.

\section{Conclusions}

1. Quantitative real-time PCR of the major bacteria groups of gut microbiota, e.g., Bifidobacterium spp., Escherichia coli, B. fragilis group, F.prausnitzii could be used as microbiological marker for evaluation of changing fecal microbiota following fecal transplantation as a routine molecular biology technique.

2.The genocopy counts of B. fragilis group correlate with clinical response in the patients with severe GvHD after alloHSCT.

3.The time course of B.fragilis group contents could be considered an index of fecal microbiota engraftment following FMT.

4. B. fragilis contents in fecal microbiota measured by multiplex PCR show high positive correlation with Shannon index of bacterial diversity, determined by $16 \mathrm{~S}$ rRNA gene sequencing.

\section{Conflict of interest}

The authors state that they have no conflict of interests.

\section{Acknowledgements}

The study was in part supported by a research contract with Russian Ministry of Healthcare effective as of January 2018 to December 2020.

\section{References}

1. Chukhlovin A.B., Pankratova O.S. Opportunistic microflora at unusual sites: marker pathogens in severe posttransplant immune deficiency. Cell Ther Transplant. 2017; 6(4): $28-41$.

2. Fujio-Vejar S, Vasquez Y, Morales P, Magne F, Vera-Wolf P, Ugalde JA, Navarrete P, Gotteland M. The gut microbiota of healthy Chilean subjects reveals a high abundance of the phylum Verrucomicrobia. Front Microbiol, 30 June 2017, https://doi.org/10.3389/fmicb.2017.01221.

3. Senghor B, Sokhna C, Ruimy R, Lagier J-C. Gut microbiota diversity according to dietary habits and geographical provenance. Hum Microbiome J. 2018; 7-8: 1-9.

4. Taur Y. Intestinal microbiome changes and stem cell transplantation: Lessons learned. Virulence. 2016, 7(8), 930938. doi: 10.1080/21505594.2016.1250982.

5. Peled JU, Gomes ALC, Devlin SM, Littmann ER, Taur Y, Sung AD et al. Microbiota as predictor of mortality in allogeneic hematopoietic-cell transplantation. N Engl J Med. 2020; 382:822-834 
6. Shouval R, Geva M, Nagler A, Youngster I. Fecal microbiota transplantation for treatment of acute graft-versus-host disease. Clin Hematol Int. 2019; 1(1): 28-35.

7. Cammarota G, Ianiro G, Kelly CR, Mullish B, Allegretti $\mathrm{JR}$, Kassam $\mathrm{Z}$ et al. International consensus conference on stool banking for faecal microbiota transplantation in clinical practice. Gut. 2019;68:2111-2121.

8. Becker SL, Chatigre JK, Gohou JP, Coulibaly JT, Leuppi R, Polmans K, Chappuis F, Mertens P, Herrmann M, Goran EKN, Utzinger J, von Müller L. Combined stool-based multiplex PCR and microscopy for enhanced pathogen detection in patients with persistent diarrhoea and asymptomatic controls from Côte d'Ivoire. Clin Microbiol Infect. 2015;21:591. e1-591.e10.

9. Zitomersky NL, Coyne MJ, Comstock LE. Longitudinal analysis of the prevalence, maintenance, and $\operatorname{IgA}$ response to species of the order Bacteroidales in the human gut. Infect Immunity, 2011, 79, 2012-2020.

10. Jo YJ, Tagele SB, Pham HQ, Jung YG, Ibal JC, Choi SD, Kang GU, Park S, Kang Y, Kim S, Koh H, Shin JH. In Situ profiling of the three dominant phyla within the human gut using TaqMan PCR for pre-hospital diagnosis of gut dysbiosis. Int J Mol Sci. 2020; 21(6): 1916. doi: 10.3390/ijms21061916.

11. Goloshchapov OV, Olekhnovich EI, Sidorenko SV, MoiseevIS, Kucher MA, Fedorov DE, Pavlenko AV, Manolov AI, Gostev VV, Veselovsky VA, Klimina KM, Kostryukova ES, Bakin EA, Shvetcov AN, Gumbatova ED, Klementeva RV, Shcherbakov AA, Gorchakova MV, J Egozcue JJ, Pawlowsky-Glahn V, Suvorova MA, Chukhlovin AB, Govorun VM, Ilina EN, Afanasyev BV. Long-term impact of fecal transplantation in healthy volunteers. BMC Microbiology. 2019; vol. 19, Article No.: 312.

12. Glucksberg H, Storb R, Fefer A, Buckner CD, Neiman PE, Clift RA et al. Clinical manifestations of graft-versus-host disease in human recipients of marrow from HL-A-matched sibling donors. Transplantation. 1974;18(4):295-304.

13. 13. Martin PJ, Bachier CR, Klingemann H-G, McCarthy PL, Szabolcs P, Uberti JP et al. Endpoints for clinical trials testing treatment of acute graft-versus-host disease: a consensus document. Biol Blood Marrow Transplant. 2009; 15(7): 777. doi:10.1016/j.bbmt.2009.03.012.

14. Lewis SJ, Heaton KW. Stool form scale as a useful guide to intestinal transit time. Scand J Gastroenterol. 1997; 32(9): 920-924.

15. Common terminology criteria for adverse events (CTCAE). Version 5.0. Published: November 27, 2017. https:// ctep.cancer.gov/protocolDevelopment/electronic_applications/docs/CTCAE_v5_Quick_Reference_8.5x11.pdf.

16. WHO guidelines on the pharmacological treatment of persistingpain in children with medical illnesses Geneva: World Health Organization; 2012. PMID: 23720867.

17. WHO Guidelines for the Pharmacological and Radiotherapeutic Management of Cancer Pain in Adults and Adolescents. Geneva: World Health Organization; 2018. https://www.who.int/ncds/management/palliative-care/cancer-pain-guidelines/en/
18. Wickham H. ggplot2: Elegant Graphics for Data Analysis. 2016. Springer-Verlag, New York.

19. Kassambara A. 2019. ggpubr: 'ggplot2' Based Publication Ready Plots. R package version 0.2.4. https://CRAN.R-project.org/package $=$ ggpubr.

20. Shono Y, Docampo MD, Peled JU, Perobelli SM, Velardi E, Tsai JJ, Slingerland AE, Smith OM, Young LF, Gupta J, Lieberman SR, Jay HV, Ahr KF, Porosnicu Rodriguez KA, $\mathrm{Xu}$ K. Increased GvHD-related mortality with broad-spectrum antibiotic use after allogeneic hematopoietic stem cell transplantation in human patients and mice. Sci Transl Med. 2016;8(339): 339ra71. doi:10.1126/scitranslmed.aaf2311.

21. El Hage R, Hernandez-Sanabria E, Van de Wiele T. Emerging trends in "Smart Probiotics": functional consideration for the development of novel health and industrial applications. Front Microbiol. 2017; DOI: 10.3389/ fmicb.2017.01889.

22. Jian C, Luukkonen P, Yki-Järvinen H, Salonen A, Korpela K. Quantitative PCR provides a simple and accessible method for quantitative microbiota profiling. PLoSOne. 2020; 15(1):e0227285. DOI: 10.1371/journal.pone.0227285. 


\title{
Bacteroides fragilis - потенциальный маркер эффек- тивной трансплантации микробиоты при лечении острой реакции «трансплантат против хозяина»
}

\author{
Олег В. Голощапов ${ }^{1}$, Евгений А. Бакин ${ }^{1}$, Максим А. Кучер ${ }^{1}$, Оксана В. Станевич ${ }^{1}$, Мария А. Суворова ${ }^{2}$, \\ Владимир В. Гостев ${ }^{3}$, Олег С. Глотов ${ }^{4}$, Юрий А. Эйсмонт ${ }^{4}$, Дмитрий Е. Полев ${ }^{5}$, Анастасия Ю. Лобенская ${ }^{5}$, \\ Руслана В. Клементьева ${ }^{1}$, Мария О. Голощапова ${ }^{1}$, Людмила С. Зубаровская ${ }^{1}$, Сергей В. Сидоренко ${ }^{3}$, \\ Александр Н. Суворов ${ }^{4}$, Иван С. Моисеев ${ }^{1}$, Алексей Б. Чухловин ${ }^{1}$ \\ ${ }^{1}$ НИИ детской онкологии, гематологии и трансплантологии им. Р. М. Горбачевой, Первый Санкт-Петербургский \\ государственный медицинский университет им. акад. И. П. Павлова, Санкт-Петербург, Россия \\ ${ }^{2}$ Научная лаборатория Эксплана, Санкт-Петербург, Россия \\ 3 Детский научно-клинический центр инфекционных болезней, Санкт-Петербург, Россия \\ ${ }^{4}$ Городская больница №40, Санкт-Петербург, Россия \\ ${ }^{5}$ ООО «Сербалаб», Санкт-Петербург, Россия \\ ${ }^{6}$ Институт экспериментальной медицины, Санкт-Петербург, Россия
}

\section{Резюме}

Показания, технология, методы контроля динамики и приживления микробиоты при трансплантации фекальной микробиоты (ТФМ), нуждаются в стандартизации. Целью работы было сравнение возможностей и результатов полимеразной цепной реакции в режиме реального времени (ПЦР) и методики $16 \mathrm{~S}-$ секвенирования для контроля динамики состава фекальной микробиоты у пациентов после ТФМ.

\section{Пациенты и методы}

В проспективное, одноцентровое исследование включено 27 пациентов с острой и хронической (overlap-синдром) реакцией «трансплантат против хозяина» (РТПХ) желудочно-кишечного тракта после аллогенной трансплантации гемопоэтических стволовых клеток (алло-ТГСК). У 19 пациентов проводили ТФМ, преимущественно, с ингестией капсул. В контрольную группу вошли 8 пациентов, получавшие плацебо. Количественные изменения бактериального состава микроорганизмов фекальной микробиоты оценивали методом ПЦР и 16S-секвенирования в сроки от 3 до 120 сут. после ТФМ. Клинический ответ определяли по 4 шкалам оценки кишечного синдрома и РТПХ.

\section{Результаты}

При оценке консистенции стула по Бристольской шкале, как показателя эффективности терапии РТПХ, полный клинический ответ к Д+120 после ФМТ отмечен в 9 случаях (47\% с оценкой Бристоля $\leq 4$ баллов), у 9 пациентов (47\%) - улучшение консистенции стула (>4 балла). В группе плацебо полный или частичный ответ был выявлен, соответственно, у 1 (13\%) и 4 (50\%) пациентов. Мультиплексная ПЦР фекальной микробиоты в режиме реального времени показала различную динамику у пациентов после ТФМ или плацебо, по сравнению с исходными уровнями до ТФМ. Общая бактериальная масса и число генокопий отдельных микробных видов значительно повышались после ТФМ. Такие изменения были особенно показательными через 30 сут. для общей микробной массы $(\mathrm{p}=0,002)$; Escherichia coli $(\mathrm{p}=0,001) ;$ Bacteroides fragilis group $(\mathrm{p}=0,05)$; Faecalibacterium prausnitzii $(\mathrm{p}=0,005)$. В то же время количества Lactobacillus spp. и Bacteroides thetaiotaomicron, в целом, не изменялись на протяжении этого периода. Кроме того, в контрольной группе не выявлено существенных изменений фекальной микробиоты против исходных уровней в течение всего периода наблюдений. Также обнаружены некоторые различия в динамике микробиоты для подгрупп с полным ответом, частичным/отсутствием ответа: Bifidobacterium spp. $(\mathrm{p}<0,047)$, E.coli $(\mathrm{p}<0,00047)$, B.fragilis group $\left(\mathrm{p}=5,6 \times 10^{-5}\right)$, F.prausnitzii $(\mathrm{p}<0,0062)$.

\section{Выводы}

Полуколичественная ПЦР основных бактериальных групп кишечной микробиоты, в т.ч. Bifidobacterium spp., Escherichia coli, B.fragilis group, F.prausnitzii может использоваться как микробиологический показатель оценки микробного ландшафта после ФМТ в качестве рутинной молекулярно-биологической методики. Число генокопий B.fragilis group коррелирует с клиническим ответом у пациентов с кишечной формой РТПХ после алло-ТГСК после процедуры ТФМ.

\section{Ключевые слова}

Реакция «трансплантат против хозяина», фекальная микробиота, трансплантация, Bacteroides fragilis, полимеразная цепная реакция, мультиплексная, секвенирование следующего поколения, ген $16 \mathrm{~S}$ рРНК. 